\title{
Deep Eutectic Solvents as Media in Alcohol Dehydrogenase- Catalyzed Reductions of Halogenated Ketones
}

\author{
Fatima Zohra Ibn Majdoub Hassani, ${ }^{[a, b]}$ Saaid Amzazi, ${ }^{[a]}$ Joseph Kreit, ${ }^{[a]}$ and Iván Lavandera ${ }^{*[b]}$
}

\begin{abstract}
The application of deep eutectic solvents (DESs) in biotechnological processes has gained an outstanding relevance, as they can be used as greener media to obtain higher productivities and selectivities. In the present contribution, a eutectic mixture composed of choline chloride $(\mathrm{ChCl})$ : glycerol $(1: 2 \mathrm{~mol} / \mathrm{mol})$ has been used as a reaction medium in combination with Tris- $\mathrm{SO}_{4} 50 \mathrm{mM}$ buffer $\mathrm{pH} 7.5$, applied to the alcohol dehydrogenase (ADH)-catalyzed reduction of various carbonyl precursors of chiral halohydrins. These alcohols are key intermediates of biologically active compounds, and hence they are of industrial interest. In the presence of up to $50 \% \mathrm{v} / \mathrm{v}$ of DES, these biotransformations were achieved up to $300-400 \mathrm{mM}$ of the $\alpha$ halogenated ketone substrate, getting access to the final compounds with excellent conversions (usually $>90 \%$ ) and enantiomeric excess (ee $>99 \%$ ). Among the different ADHs tested, two stereocomplementary enzymes (Lactobacillus brevis $\mathrm{ADH}$ and Rhodococcus ruber ADH) afforded the best results, so both alcohol enantiomers could be obtained in all the studied examples. Selected bioreductions were scaled up to $250 \mathrm{mg}$ and $1 \mathrm{~g}$, demonstrating the potential that DESs can offer as media in redox processes for substrates with low solubility in water.
\end{abstract}

\section{Introduction}

In the last years, the synthesis of chiral halohydrins has received great attention due to their synthetic versatility and high reactivity. They have become privileged scaffolds to access biologically active derivatives. They are precursors of $\beta$-adrenoreceptor blockers $^{[1]}$ and also key intermediates of various active ingredients of medicaments that are currently commercialized. Examples of these compounds (Figure 1) include mirabegron ${ }^{[2]}$ and ezetimibe, ${ }^{[3]}$ used for treatment of overactive bladder and hypercholesterolemia, respectively.

Among the plethora of synthetic methods to synthesize halohydrins in enantioenriched form, probably the most employed

[a] F. Z. Ibn Majdoub Hassani, Prof. S. Amzazi, Prof. J. Kreit Biochemistry and Immunology Laboratory, Faculty of Sciences Mohammed V University BP 1014, Avenue Ibn Batouta Agdal, Rabat 10090, Morocco

[b] F. Z. Ibn Majdoub Hassani, Prof. I. Lavandera Organic and Inorganic Chemistry Department University of Oviedo

Avenida Julián Clavería 8, 33006 Oviedo, Spain E-mail: lavanderaivan@uniovi.es

Supporting information for this article is given via a link at the end of the document. is the reduction of the $\alpha$-halogenated ketone precursors. Hence, the use of metals as catalysts has provided appreciable results, ${ }^{[4]}$ but from an environmental point of view and selectivity, the utilization of enzymes is more desirable. In fact, in the recent literature, many examples can be found employing alcohol dehydrogenases (ADHs), ${ }^{[5]}$ in order to obtain chiral halohydrins. These $N A D(P)$-dependent oxidoreductases have provided impressive results in terms of activity and selectivity under mild conditions. Thus, whole cells ${ }^{[6]}$ and isolated or overexpressed enzymes $^{[7]}$ have been utilized for this purpose.

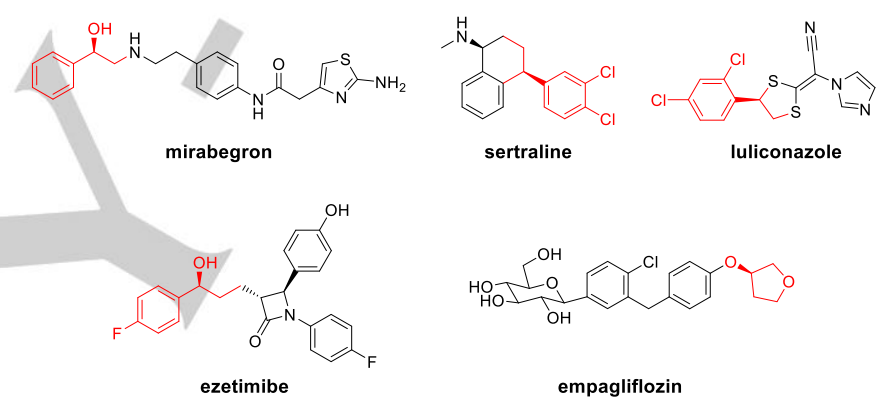

Figure 1. Examples of active ingredients of commercialized medicaments where halohydrins are key intermediates (the part of the molecule derived from the halohydrin appears in red).

Aqueous medium is the natural environment for these biocatalysts, but it has been discovered that they can work in nonconventional media containing organic solvents ${ }^{[8]}$ or ionic liquids (ILs). ${ }^{[9]}$ This can be advantageous for these enzymes due to the large hydrophobicity of the organic substrates, making feasible the employment of higher substrate concentrations and therefore, higher productivities. Related to this fact, new types of ionic liquids that are ecologically more convenient than the organic solvents, are the (natural) deep eutectic solvents (NA)DESs. ${ }^{[10]}$ They are typically made of a hydrogen bond donor (HBD, such as glycerol, ethylene glycol or urea), and a quaternary ammonium salt acting as a hydrogen bond acceptor (HBA, e.g. choline chloride, $\mathrm{ChCl}$ ). The intermolecular interactions between these components provide specific properties for these neoteric solvents. Among their advantages, it can be highlighted that they can easily be prepared from cheap precursors, and they are composed of natural, and therefore degradable, constituents. Their biocompatibility with redox enzymes has been well documented. ${ }^{[11]}$ DESs have been mostly applied with (multienzymatic) whole cell systems to modify the stereoselectivity of bioreduction processes, due to the specific inhibition of some of the enzymes present in the cell. ${ }^{[12]}$ Also, they 
have been found as suitable media for preparations which overexpress $\mathrm{ADHs},{ }^{[13]}$ and even for nicotinamide cofactor recycling purposes. ${ }^{[14]}$

To the best of our knowledge, there is just one report that describes the bioreduction of an $\alpha$-halogenated ketone using whole cells in a medium containing DESs. ${ }^{[15]}$ Herein, we have focused on the development of efficient reduction processes by utilizing overexpressed ADHs to synthesize various enantiopure halohydrins, key precursors of biologically active compounds, studying the influence in the reaction mixture of a eutectic solvent composed of choline chloride and glycerol $(1: 2 \mathrm{~mol} / \mathrm{mol})$.

\section{Results and Discussion}

In the present study, we used lyophilized preparations of $E$. coll overexpressing the $(R)$-selective $\mathrm{ADH}$ from Lactobacillus brevis $(\mathrm{LBADH})^{[16]}$ and the (S)-selective ADHs from Rhodococcus ruber $(\mathrm{ADH}-\mathrm{A}),{ }^{[17]}$ Thermoanaerobacter ethanolicus (TeSADH), ${ }^{[18]}$ and Thermoanaerobacter sp. (ADH-T). ${ }^{[19]}$ These preparations were employed due to their advantages regarding other enzymatic formulations in terms of higher stability and easy handling. ${ }^{[20]}$ From a previous work in our research group ${ }^{[13 a]}$ we already knew that the ChCl:glycerol (1:2 $\mathrm{mol} / \mathrm{mol})$ DES mixture was compatible with these ADHs. Also, this mixture presents an adequate viscosity, therefore no mass-transfer limitations were expected even at large DES concentrations in the reaction medium. Therefore, we focused on the bioreduction of 8 halogenated ketones (1-8a, Table 1), in the presence of this eutectic mixture at $20 \%$ and $50 \% \mathrm{v} / \mathrm{v}$ in Tris- $\mathrm{SO}_{4}$ buffer ${ }^{[21]} 50 \mathrm{mM} \mathrm{pH} 7.5$ (Table 1 and Tables S2-S9 in the Supporting Information). In order to recycle the nicotinamide cofactor (1 $\mathrm{mM})$, propan-2-ol was used as hydrogen donor in a "coupled-substrate" approach. ${ }^{[22]}$ The reduction of $\alpha$-halogenated carbonyl compounds is favored thermodynamically. ${ }^{[23]}$ Therefore, it is not necessary to employ an elevated molar excess of the co-substrate to achieve quantitative conversions.

From the initial enzyme screening with substrate 1a (Table S2 in the Supporting Information), it was clear that the best choices to accomplish the reduction processes were stereocomplementary $\mathrm{ADH}-\mathrm{A}^{[17]}$ and $\mathrm{LBADH} .{ }^{[16]}$ It must be noted that ADH-A afforded the $(R)$-alcohols while LBADH the $(S)$ antipodes. This is simply due to a change in the Cahn-IngoldPrelog (CIP) priority of the alcohol substituents. The absolute configuration of these alcohols was assigned based on previous examples described in the literature and also by comparison of the GC retention times and optical rotation values (for more information, see Section 4 in the Supporting Information). As can be seen in Table 1, both ADHs catalyzed the bioreductions in the presence of a high amount of DES $(50 \% \mathrm{v} / \mathrm{v})$ in the reaction medium, providing the desired aromatic or aliphatic halohydrins $(R)$ - or (S)-1-8b with excellent conversions and enantiomeric excess $(e e)$. Due to the mildness of these processes, no byproducts (e.g., epoxides) were detected in the reaction mixtures.
Table 1. Bioreduction of halogenated ketones 1-8a $(20 \mathrm{mM})$ in the presence of DES $(50 \% \mathrm{v} / \mathrm{v})$. $^{[\mathrm{a}]}$

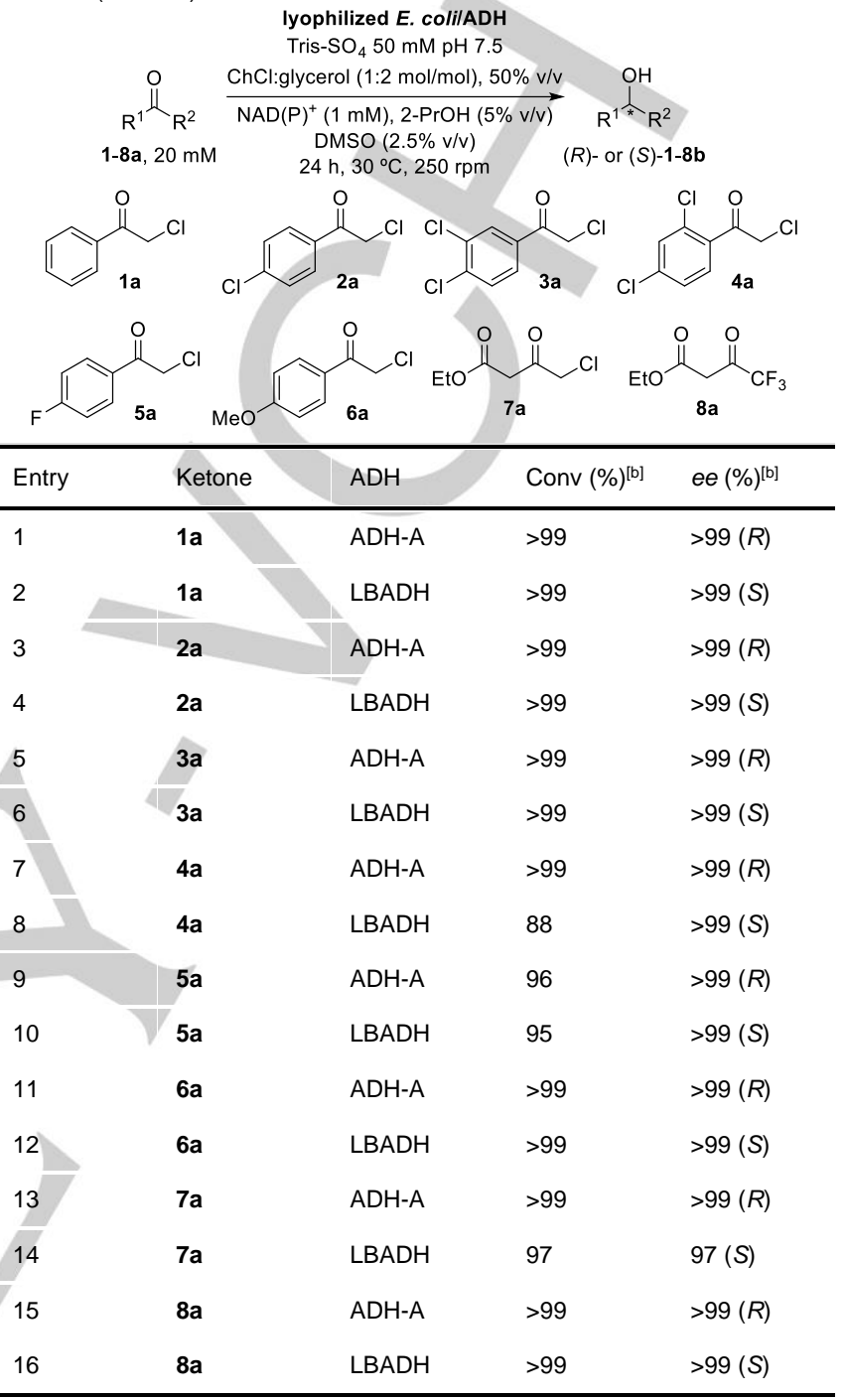

[a] For reaction conditions, see the Experimental Section. [b] Measured by chiral GC. There is a change in the CIP priority.

Due to the fact that the substrate concentration in these reduction protocols was still modest $(20 \mathrm{mM})$, we decided to increase it while maintaining the same amount of the biocatalyst and the cofactor in the experiments. We usually performed the bioreductions at $20 \% \mathrm{v} / \mathrm{v}$ and $50 \% \mathrm{v} / \mathrm{v}$ of DES, and compared the results with the reactions in plain buffer. As shown in Tables S2S9 in the Supporting Information, in most cases the ketone concentration could be effectively increased up to $300-400 \mathrm{mM}$ when employing $20 \% \mathrm{v} / \mathrm{v}$ of DES. However, slightly lower conversions were observed at these substrate concentrations in the presence of $50 \% \mathrm{v} / \mathrm{v}$ of DES. Meanwhile, the stereoselectivity of all these reactions remained elevated for both $\mathrm{ADHs}$, so that the synthesis of both halohydrin enantiomers was feasible. For comparison, the same transformations were performed in plain buffer, obtaining in some cases comparable results, but for some reductions better conversions were achieved in the presence of 
DES, as shown in Figure 2. We think that the cosolvent can be beneficial in terms of a better substrate solubility and therefore mass transfer. An advantage of employing lyophilized whole cells is that the cell walls are partially disrupted and therefore the substrate can be more available for the in-cell enzyme.

A)

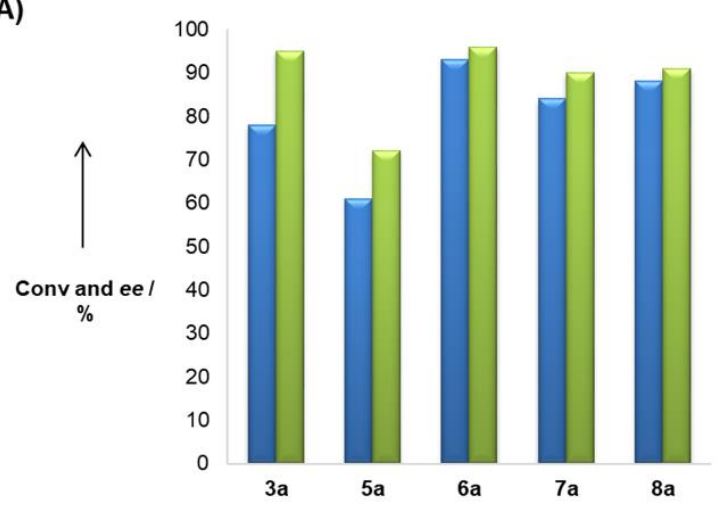

$(400 \mathrm{mM})(500 \mathrm{mM})(300 \mathrm{mM})(500 \mathrm{mM})(400 \mathrm{mM})$

B)

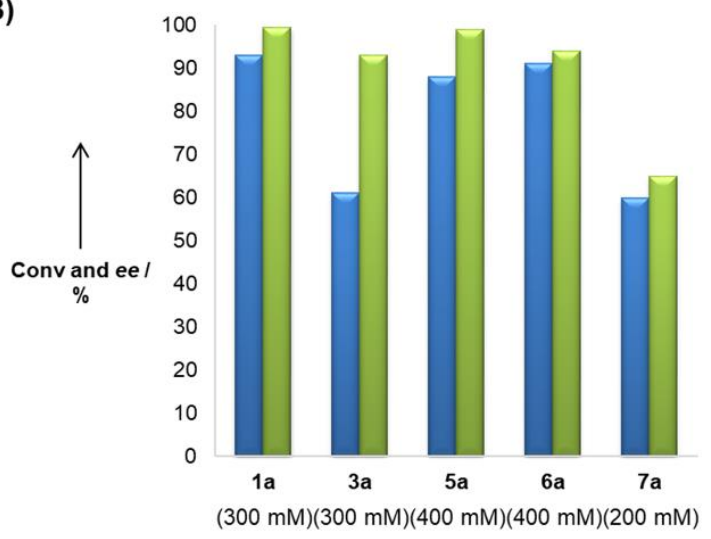

Figure 2. Comparison between conversions for some selected bioreductions with: A) E. coli/ADH-A; and B) E. coli/LBADH in plain buffer (blue bars) and in the presence of $\mathrm{ChCl}$ :glycerol $(1: 2 \mathrm{~mol} / \mathrm{mol}) \mathrm{DES}$ at $20 \% \mathrm{v} / \mathrm{v}$ (green bars). In all cases, the obtained ee values were $>99 \%$.

The cofactor is already present in the whole cell preparation, and although in lyophilized $E$. coli cells it can diffuse to the reaction medium, its external addition could not be of absolute necessity, as the biotransformation occurring favors the diffusion inside the cells. In a set of experiments, the bioreductions in the presence of DES were performed at $200 \mathrm{mM}$ ketone concentration without adding the nicotinamide cofactor. While for NADP-dependent LBADH, the results were not satisfactory (data not shown), for NAD-dependent ADH-A, high conversions were achieved, especially when using $20 \% \mathrm{v} / \mathrm{v}$ of DES (Table 2 and Table $\mathrm{S} 10$ in the Supporting Information). This can be explained by the fact that there is a higher cytosolic concentration of $\mathrm{NADH} / \mathrm{NAD}^{+}$with respect to $\mathrm{NADPH} / \mathrm{NADP}^{+}$in E. coli cells. ${ }^{[24]}$
Table 2. Bioreduction of halogenated ketones 1-8a $(200 \mathrm{mM})$ with $E$. coli/ADH-A in the presence of DES $(20 \% \mathrm{v} / \mathrm{v})$ and without external addition of the cofactor $\mathrm{NAD}^{+}$. [a]

$$
\begin{gathered}
\begin{array}{c}
\text { lyophilized } \text { E. colilADH-A } \\
\text { Tris-SO }_{4} 50 \mathrm{mM} \mathrm{pH} 7.5
\end{array} \\
\stackrel{\text { ChCl:glycerol }(1: 2 \mathrm{~mol} / \mathrm{mol}), 20 \% \mathrm{v} / \mathrm{v}}{\mathrm{DMSO}(2.5 \% \mathrm{v} / \mathrm{v}), 2-\mathrm{PrOH}(5 \% \mathrm{v} / \mathrm{v})}
\end{gathered}
$$

\begin{tabular}{llll}
\multicolumn{1}{c}{$\mathbf{1 - 8 a}, 200 \mathrm{mM}$} & $24 \mathrm{~h}, 30^{\circ} \mathrm{C}, 250 \mathrm{rpm}$ & $(R)-1-8 \mathbf{b}$ \\
\hline Entry & Ketone & Conv $(\%)^{[\mathrm{b}]}$ & ee $(\%)^{[\mathrm{b}]}$ \\
\hline 1 & $\mathbf{1 a}$ & 82 & $>99(R)$ \\
2 & $\mathbf{2 a}$ & 71 & $>99(R)$ \\
3 & $\mathbf{3 a}$ & $>99$ & $>99(R)$ \\
4 & $\mathbf{4 a}$ & 97 & $>99(R)$ \\
5 & $\mathbf{5 a}$ & $>99$ & $>99(R)$ \\
6 & $\mathbf{6 a}$ & 97 & $>99(R)$ \\
7 & $\mathbf{7 a}$ & $>99$ & $>99(R)$ \\
8 & $\mathbf{8 a}$ & 97 & $>99(R)$ \\
\hline
\end{tabular}

[a] For reaction conditions, see the Supporting Information. [b] Measured by chiral GC.

In order to demonstrate the applicability of this methodology, $\mathrm{ADH}$-catalyzed transformations in the presence of DES were performed at a preparative scale (Figure 3). This way, $250 \mathrm{mg}$ of target ketones 1-8a and an extra experiment with substrate $\mathbf{4 a}$ at $1 \mathrm{~g}$-scale were performed to synthesize the corresponding enantiopure halohydrins. The products could easily be isolated after a liquid-liquid extraction protocol in high yields.

\section{Conclusions}

This contribution demonstrates that eutectic mixtures can improve the productivity in oxidoreductase-mediated transformations to synthesize relevant chiral halohydrins at high concentrations. Lyophilized E. coli whole cells overexpressing ADHs have been used in a mixture of aqueous buffer and DES (ChCl: glycerol 1:2 $\mathrm{mol} / \mathrm{mol}$ ) up to $50 \% \mathrm{v} / \mathrm{v}$. This medium did not affect negatively the activity and selectivity of two stereocomplementary ADHs, namely Lactobacillus brevis ADH and Rhodococcus ruber ADH, obtaining better results in the presence of $20 \% \mathrm{v} / \mathrm{v}$ of the cosolvent. Hence, the bioreductions of various $\alpha$-halogenated ketones could be performed up to $300-400 \mathrm{mM}$ achieving high conversions (usually $>90 \%$ ) and excellent enantiomeric excess (>99\%). The possibility of avoiding the external addition of the cofactor NAD in ADH-Amediated reductions was also feasible, performing the reactions at $200 \mathrm{mM}$. These biotransformations were scaled up to $1 \mathrm{~g}$ giving access to a series of enantiopure halohydrins. Overall, the present study shows a good example where the combination of DESs with lyophilized whole cell systems overexpressing a biocatalyst can be beneficial in a biotransformation and shows the great potential that these cheap and environmentally friendly solvents can possess for biotechnological applications. 


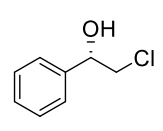

E. coli/LBADH, DES $20 \%, 300 \mathrm{mM}$ (S)-1b, $82 \%$ yield, $>99 \%$ ee<smiles>O[C@H](CCl)c1ccc(Cl)cc1Cl</smiles>

E. colilADH-A, DES $20 \%, 300 \mathrm{mM}$ (R)-4b, $89 \%$ yield, $>99 \%$ ee<smiles>O[C@H](CCl)c1ccc(Cl)cc1</smiles>

E. colilADH-A, DES $20 \%, 400 \mathrm{mM}$ (R)-2b, $63 \%$ yield, $>99 \%$ ee

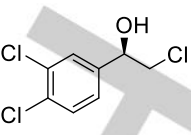

E. colilADH-A, DES $50 \%, 300 \mathrm{mM}$

(R)-3b, $79 \%$ yield, $>99 \%$ ee<smiles>O[C@H](CCl)c1ccc(F)cc1</smiles>

E. colilADH-A, DES $20 \%, 400 \mathrm{mM}$ (R)-5b, $76 \%$ yield, $>99 \%$ ee

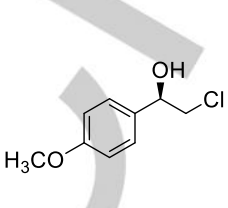

E. colilADH-A, DES $20 \%, 300 \mathrm{mM}$ $(R)-6 b, 90 \%$ yield, $>99 \%$ ee<smiles>CCOC(=O)C[C@@H](O)CCl</smiles>

E. colilADH-A, DES $50 \%, 300 \mathrm{mM}$ (R)-7b, $92 \%$ yield, $>99 \%$ ee

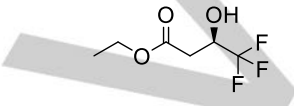

E. colilADH-A, DES $20 \%, 300 \mathrm{mM}$ (R)-8b, $66 \%$ yield, $>99 \%$ ee

Figure 3. Preparative transformations at $250 \mathrm{mg}$ (black color) and $1 \mathrm{~g}$-scale (blue color) to synthesize enantiopure halohydrins in the presence of DES.

\section{Experimental Section}

General procedure for the enzymatic reduction of halogenated ketones in the presence of a deep eutectic solvent

In a $1.5 \mathrm{~mL}-$ Eppendorf vial, the reaction mixture (final volume: $0.6 \mathrm{~mL}$ ), contains: $10 \mathrm{mg}$ of the corresponding E. coli/ADH lyophilized cells, Tris$\mathrm{SO}_{4}$ buffer $50 \mathrm{mM} \mathrm{pH} 7.5, \mathrm{NAD}(\mathrm{P})^{+}(1 \mathrm{mM})$, DES (ChCl: glycerol 1:2 $\mathrm{mol} / \mathrm{mol}, 20 \%$ or $50 \% \mathrm{v} / \mathrm{v})$, propan-2-ol $(5-15 \% \mathrm{v} / \mathrm{v})$ and the halogenated ketone (1-8a, Table 1, 20-500 mM), dissolved in DMSO. The final amount of DMSO in the assay was between $2.5-5 \% \mathrm{v} / \mathrm{v}$. The reduction reactions were carried out during $24 \mathrm{~h}$, at $30^{\circ} \mathrm{C}$ in an orbital shaker at $250 \mathrm{rpm}$. The crude was extracted with ethyl acetate $(2 \times 500 \mu \mathrm{L})$. The organic layers were collected by centrifugation, combined, and dried over $\mathrm{Na}_{2} \mathrm{SO}_{4}$. Conversion rates and enantiomer excess of the halohydrins were determined by GC on a chiral column (see the Supporting Information). To determine the ee values for halohydrins $\mathbf{7 b}$ and $\mathbf{8 b}$, an acetylation step was required. 4-Dimethylaminopyridine (DMAP, $1 \mathrm{mg}$ ) and acetic anhydride $(30 \mu \mathrm{L})$ were mixed and then added to a volume of $200 \mu \mathrm{L}$ of the extracted reaction crude solution. The mixture was shaken for $3 \mathrm{~h}$ at $30{ }^{\circ} \mathrm{C}$, and then quenched with $0.5 \mathrm{~mL}$ water for $30 \mathrm{~min}$. The acetylated alcohol was extracted with ethyl acetate $(2 \times 500 \mu \mathrm{L})$, and the combined organic phases were dried over $\mathrm{Na}_{2} \mathrm{SO}_{4}$, and subjected to $\mathrm{GC}$ analysis.

\section{Scale-up of the bioreduction of $4 \mathrm{a}(1 \mathrm{~g}, 300 \mathrm{mM})$ in the presence of} DES $(20 \% \mathrm{v} / \mathrm{v})$

In an Erlenmeyer flask, $500 \mathrm{mg}$ of $E$. coli/ADH-A were introduced. Then, $10.6 \mathrm{~mL}$ of Tris-SO $50 \mathrm{mM} \mathrm{pH} 7.5$ buffer, $1.5 \mathrm{~mL}$ of the NAD+ solution (10 $\mathrm{mM}$ in Tris- $\mathrm{SO}_{4} 50 \mathrm{mM} \mathrm{pH} \mathrm{7.5)}$ and $3.2 \mathrm{~mL}(20 \% \mathrm{v} / \mathrm{v})$ of DES were added in the Erlenmeyer flask. Then, $1.2 \mathrm{~mL}$ of propan-2-ol and $1 \mathrm{~g}$ of 2,2',4'trichloroacetophenone were introduced. The flask was closed and the reaction was shaken for $24 \mathrm{~h}$ at $30^{\circ} \mathrm{C}$ in an orbital shaker at $250 \mathrm{rpm}$. The supernatant of the bioreduction mixture was collected by centrifugation and transferred into an extraction funnel. The deposited pellet was washed with ethyl acetate $(30 \mathrm{~mL})$ to extract the residual substrate and product in the Falcon tube by centrifugation, and it was pooled into the funnel with the previous organic phase. This organic solvent was washed with water $(20 \mathrm{~mL})$. The phases in the funnel were separately collected. The aqueous phase was again extracted with ethyl acetate $(50 \mathrm{~mL})$. This organic phase was combined with the previous one to yield a combined extract that was washed with water (10 $\mathrm{mL}$, to eliminate the residual glycerol), collected in an Erlenmeyer flask, dried over $\mathrm{Na}_{2} \mathrm{SO}_{4}$ and filtered into a round-bottom flask. $\mathrm{Na}_{2} \mathrm{SO}_{4}$ was washed with ethyl acetate $(10 \mathrm{~mL})$. The solvent was evaporated under reduced pressure, affording the alcohol $(R)-\mathbf{4 b}(900 \mathrm{mg}$ $89 \%$ yield) in $>99 \%$ ee.

\section{Acknowledgements}

Financial support from the Spanish Ministry of Economy and Competitiveness (MEC, Project CTQ2016-75752-R) is gratefully acknowledged. We thank Prof. Wolfgang Kroutil (University of Graz, Austria) for providing us with alcohol dehydrogenases overexpressed in E. coli cells.

Keywords: deep eutectic solvents • alcohol dehydrogenases • bioreduction $\cdot$ selectivity $\cdot$ halohydrins

[1] D. Żelaszczyk, K. Kieć-Kononowicz, Curr. Med. Chem. 2007, 14, 53-65.

[2] T. Maruyama, T. Suzuki, K. Onda, M. Hayakawa, H. Moritomo, T. Kimizuka, T. Matsui (Yamanouchi Pharmaceutical Co.), WO 9920607 A1, 1999

[3] S. B. Rosenblum, S. Dugar, D. A. Burnett, J. W. Clader, B. A. McKittrick (Schering Corp.), WO 9508532 A1, 1995

[4] Selected recent examples: a) Y. Yuki, T. Touge, H. Nara, K. Matsumura, M. Fujiwhara, Y. Kayaki, T. Ikariya, Adv. Synth. Catal. 2018, 360, 568 
574; b) C. Yin, W. Wu, Y. Hu, X. Tan, C. You, Y. Liu, Z. Chen, X.-Q. Dong, X. Zhang, Adv. Synth. Catal. 2018, 360, 2119-2124; c) C. K. Blasius, V. Vasilenko, L. H. Gade, Angew. Chem. Int. Ed. 2018, 57, 10231-10235 Angew. Chem. 2018, 130, 10388-10392.

[5] Recent reviews: a) S. de Wildeman, N. Sereinig in Science of Synthesis, Stereoselective Synthesis, Vol. 2 (Eds.: J. G. De Vries, G. A. Molander P. A. Evans), Georg Thieme Verlag, Stuttgart, 2011, pp. 133-208; b) C. M. Nealon, M. M. Musa, J. M. Patel, R. S. Phillips, ACS Catal. 2015, 5, 2100-2114; c) T. S. Moody, S. Mix, G. Brown, D. Beecher in Science of Synthesis, Biocatalysis in Organic Synthesis, Vol. 2 (Eds.: K. Faber, W. D. Fessner, N. J. Turner), Georg Thieme Verlag, Stuttgart, 2015, pp. 421458; d) R. Zhang, Y. Xu, R. Xiao, Biotechnol. Adv. 2015, 33, 1671-1684.

[6] C. Aguirre-Pranzoni, F. R. Bisogno, A. A. Orden, M. Kurina-Sanz, J. Mol. Catal. B: Enzym. 2015, 114, 19-24.

[7] Selected recent examples: a) D. Zhu, C. Mukherjee, L. Hua, Tetrahedron: Asymmetry 2005, 16, 3275-3278; b) J. Mangas-Sánchez, E. Busto, V. Gotor-Fernández, F. Malpartida, V. Gotor, J. Org. Chem 2011, 76, 2115-2122; c) R. Zuhse, C. Leggewie, F. Hollmann, S. Kara Org. Process Res. Dev. 2015, 19, 369-372; d) G.-C. Xu, Y.-P. Shang, H.L. Yu, J.-H. Xu, Chem. Commun. 2015, 51, 15728-15731; e) G.-C. Xu, H.-L. Yu, Y.-P. Shang, J.-H. Xu, RSC Adv. 2015, 5, 22703-22711; f) M. L. Contente, I. Serra, F. Molinari, R. Gandolfi, A. Pinto, D. Romano, Tetrahedron 2016, 72, 3974-3979; g) Y. Zhang, H. Wang, L. Chen, K. Wu, J. Xie, D. Wei, J. Mol. Catal. B: Enzym. 2016, 134, 51-60; h) F. Qin, B. Qin, T. Mori, Y. Wang, L. Meng, X. Zhang, X. Jia, I. Abe, S. You, ACS Catal. 2016, 6, 6135-6140; i) A. Li, L. Ye, X. Yang, C. Yang, J. Gu, H. Yu, Chem. Commun. 2016, 52, 6284-6287; j) Y.-P. Shang, Q. Chen, X.-D. Kong, Y.-J. Zhang, J.-H. Xu, H.-L. Yu, Adv. Synth. Catal. 2017, 359, 426431 ; k) G.-W. Zheng, Y.-Y. Liu, Q. Chen, L. Huang, H.-L. Yu, W.-Y. Lou, C.-X. Li, Y.-P. Bai, A.-T. Li, J.-H. Xu, ACS Catal. 2017, 7, 7174-7181; I) X. Chen, H. Zhang, J. Feng, Q. Wu, D. Zhu, ACS Catal. 2018, 8, 3525 $3531 ;$ m) F. Qin, B. Qin, W. Zhang, Y. Liu, X. Su, T. Zhu, J. Ouyang, J. Guo, Y. Li, F. Zhang, J. Tang, X. Jia, S. You, ACS Catal. 2018, 8, 6012 6020; n) S. Cai, N. Shao, Y. Chen, A. Li, J. Pan, H. Zhu, H. Zou, S. Zeng, L. Sun, J. Zhao, Org. Lett. 2019, 21, 4411-4414.

[8] a) G. de Gonzalo, I. Lavandera, K. Faber, W. Kroutil, Org. Lett. 2007, 9, 2163-2166; b) I. Lavandera, A. Kern, M. Schaffenberger, J. Gross, A. Glieder, S. de Wildeman, W. Kroutil, ChemSusChem 2008, 1, 431-436; c) A. Jakoblinnert, R. Mladenov, A. Paul, F. Sibilla, U. Schwaneberg, M. B. Ansorge-Schumacher, P. Domínguez de María, Chem. Commun. 2011, 47, 12230-12232.

[9] G. de Gonzalo, I. Lavandera, K. Durchschein, D. Wurm, K. Faber, W. Kroutil, Tetrahedron: Asymmetry 2007, 18, 2541-2546.

[10] a) Q. H. Zhang, K. D. Vigier, S. Royer, F. Jerome, Chem. Soc. Rev. 2012 41, 7108-7146; b) E. L. Smith, A. P. Abbott, K. S. Ryder, Chem. Rev. 2014, 114, 11060-11082; c) A. Paiva, R. Craveiro, I. Aroso, M. Martins, R. L. Reis, A. R. C. Duarte, ACS Sustainable Chem. Eng. 2014, 2, 10631071; d) N. Guajardo, C. R. Müller, R. Schrebler, C. Carlesi, P. Domínguez de María, ChemCatChem 2016, 8, 1020-1027; e) D. A Alonso, A. Baeza, R. Chinchilla, G. Guillena, I. M. Pastor, D. J. Ramón Eur. J. Org. Chem. 2016, 612-632.
[11] a) V. Gotor-Fernández, C. E. Paul, J. Biotechnol. 2019, 293, 24-35; b) F. Z. Ibn Majdoub Hassani, S. Amzazi, I. Lavandera, Molecules 2019, 24 2190.

[12] a) Z. Maugeri, P. Domínguez de María, ChemCatChem 2014, 6, 1535 1537; b) M. C. Bubalo, M. Mazur, K. Radošević, I. R. Redovniković Process Biochem. 2015, 50, 1788-1792; c) P. Xu, Y. Xu, X.-F. Li, B.-Y Zhao, M.-H. Zong, W.-Y. Lou, ACS Sustainable Chem. Eng. 2015, 3, 718-724; d) P. Xu, P.-X. Du, M.-H. Zong, N. Li, W.-Y. Lou, Sci. Rep. 2016 6, 26158; e) P. Vitale, V. M. Abbinante, F. M. Perna, A. Salomone, C. Cardellicchio, V. Capriati, Adv. Synth. Catal. 2017, 359, 1049-1057.

[13] a) C. R. Müller, I. Lavandera, V. Gotor-Fernández, P. Domínguez de María, ChemCatChem 2015, 7, 2654-2659; b) L. Cicco, N. RíosLombardía, M. J. Rodríguez-Álvarez, F. Morís, F. M. Perna, V. Capriati, J. García-Álvarez, J. González-Sabín, Green Chem. 2018, 20, 34683475.

[14] Á. Mourelle-Insua, I. Lavandera, V. Gotor-Fernández, Green Chem. 2019, 21, 2946-2951.

[15] Y. Dai, B. Huan, H.-S. Zhang, Y.-C. He, Appl. Biochem. Biotechnol. 2017 $181,1347-1359$

[16] a) M. Wolberg, W. Hummel, C. Wandrey, M. Müller, Angew. Chem. Int Ed. 2000, 39, 4306-4308; Angew. Chem. 2000, 112, 4476-4478; b) S. Leuchs, L. Greiner, Chem. Biochem. Eng. Q. 2011, 25, 267-281.

[17] W. Stampfer, B. Kosjek, C. Moitzi, W. Kroutil, K. Faber, Angew. Chem Int. Ed. 2002, 41, 1014-1017; Angew. Chem. 2002, 114, 1056-1059.

[18] C. Heiss, M. Laivenieks, J. G. Zeikus, R. S. Phillips, Bioorg. Med. Chem. 2001, 7, 1659-1666

[19] Z. Findrik, D. Vasić-Racki, S. Lütz, T. Daussmann, C. Wandrey, Biotechnol. Lett. 2005, 27, 1087-1095.

[20] Selected examples where lyophilized whole cells have been successfully used: a) W. Stampfer, B. Kosjek, K. Faber, W. Kroutil, J. Org. Chem. 2003, 68, 402-406; b) K. Goldberg, K. Edegger, W. Kroutil, A. Liese Biotechnol. Bioeng. 2006, 95, 192-198; c) J. Wachtmeister, A. Jakoblinnert, J. Kulig, H. Offermann, D. Rother, ChemCatChem 2014, 6 1051-1058; d) J. Wachtmeister, P. Mennicken, A. Hunold, D. Rother, ChemCatChem 2016, 8, 607-614; e) J. Poplonski, T. Reiter, W. Kroutil, Chem CatChem 2018, 10, 763-768.

[21] Phosphate buffer can be indistinctly used as reaction medium.

[22] W. Kroutil, H. Mang, K. Edegger, K. Faber, Curr. Opin. Chem. Biol. 2004, 8, 120-126.

[23] a) I. Lavandera, A. Kern, V. Resch, B. Ferreira-Silva, A. Glieder, W. M. F. Fabian, S. de Wildeman, W. Kroutil, Org. Lett. 2008, 10, 2155-2158 b) F. R. Bisogno, I. Lavandera, W. Kroutil, V. Gotor, J. Org. Chem. 2009, 74, 1730-1732; c) F. R. Bisogno, E. García-Urdiales, H. Valdés, I. Lavandera, W. Kroutil, D. Suárez, V. Gotor, Chem. Eur. J. 2010, 16 11012-11019; d) F. R. Bisogno, A. Cuetos, A. A. Orden, M. Kurina-Sanz, I. Lavandera, V. Gotor, Adv. Synth. Catal. 2010, 352, 1657-1661; e) W. Borzęcka, I. Lavandera, V. Gotor, J. Org. Chem. 2013, 78, 7312-7317.

[24] R. Lundquist, B. M. Olivera, J. Biol. Chem. 1971, 246, 1107-1116. 


\section{Entry for the Table of Contents}

\section{FULL PAPER}

A deep eutectic solvent composed of choline chloride:glycerol $(1: 2 \mathrm{~mol} / \mathrm{mol})$ has been used as cosolvent in the alcohol dehydrogenase-catalyzed bioreduction of a series of $a$ halogenated ketones employing lyophilized $E$. coli cells overexpressing the enzyme. Various halohydrins were obtained at high concentration (up to $500 \mathrm{mM}$ ) with high conversions and enantiomeric excess
Fatima Zohra Ibn Majdoub Hassani,

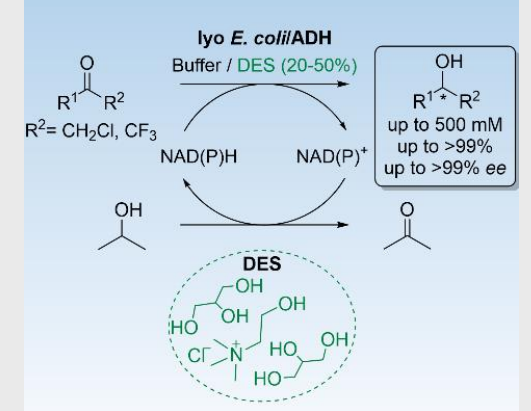
Saaid Amzazi, Joseph Kreit, and Iván Lavandera* $^{*}$

\section{Page No. - Page No.}

Deep Eutectic Solvents as Media in Alcohol Dehydrogenase-Catalyzed Reductions of Halogenated Ketones 